\title{
THE EUROZONE TARGET-SYSTEM FROM THE PERSPECTIVE OF PORTUGAL*
}

\author{
Raquel R. da COSTA - Sérgio LAGOA \\ (Received: 14 March 2016; revision received: 9 February 2018; \\ accepted: 19 February 2018)
}

\begin{abstract}
Payment systems make a significant contribution to the flow of transactions and financial stability. In this paper, we start by applying the principles of the gravity model to explain the TARGET flows of banking transactions between Portugal and other eurozone countries. The main explanatory variables tested are a composite indicator of economic and financial activities, distance, membership of the Eurozone (EZ), and country risk measured by treasury bond yields. The results indicate that Portugal has a high level of integration in the European banking market as distance is not statistically significant, and that the membership of the EZ facilitates the financing of the economy. The economic size of the partner country becomes non-significant after controlling for country fixed effects. The increase in the Portuguese country risk during the European sovereign debt crisis led to a marked decline in external financing, indicating that this is an important channel of transmission of crises.
\end{abstract}

Keywords: Gravity Model, cross-border transactions, payment systems, TARGET2

JEL classification indices: C33, E59

* The views and opinions expressed in this article are those of the authors and do not necessarily reflect the official policy or position of Banco de Portugal. We thank Banco de Portugal for granting access to the data on TARGET flows. The authors ackowledge helpful comments and suggestions from two anonymous referees.

Raquel R. da Costa, Adviser, Banco de Portugal, Lisboa, Portugal. E-mail: rscosta@bportugal.pt

Sérgio Lagoa, corresponding author. Assistant Professor, ISCTE - Instituto Universitário de Lisboa, Lisboa, Portugal. E-mail: sergio.lagoa@iscte-iul.pt 


\section{INTRODUCTION}

Banking payment systems incorporate infrastructures to support payments between financial institutions. Given their important contribution to financial stability as the enablers of transactions, the correct and efficient operation of those infrastructures is vital (Kokkola 2010).

The second generation Trans-European Automated Real-time Gross Settlement Express Transfer System 2 (TARGET2) is the most used payment system in the European Union (EU). This system is a single shared platform with harmonised rules for participants, in which settlements take place in central bank money (i.e. the funds can be re-used immediately) and there is a line of intra-day credit to eligible participants. These are some of the TARGET2's features that ensure the continuity of payments between banks and mitigate transaction risks, such as legal, credit, liquidity and operational risks (Bech et al. 2008), which can lead to systemic risk in periods of financial stress (Bandt - Hartmann 2000).

One of the main problems affecting the Eurozone (EZ) is the current account imbalances between the "core" and the "periphery", which result in TARGET imbalances. The way these imbalances evolved in the turbulent period from 2007 to 2012 provides key information that sheds light on the functioning of the EZ.

The issue raised in the present article is whether distance and economic activity affect cross-border transactions received by Portugal in the TARGET2-PT ${ }^{1}$ system. First, the principles of Gravity Models (GM) are used to explain the amount of transnational operations received annually in TARGET2-PT between 1999 and 2012. Afterwards, we evaluate the effect of the European Area (EA) sovereign debt crisis on the payment structure. In addition, we are interested in, whether Portugal carries out transactions with a limited number of countries, which may imply a high risk in some countries and stop the flow of funds (Rosati - Secola 2006).

In general, few studies apply GMs to interbank transactions, one exception being Rosati - Secola (2006), who studied the average amount of TARGET crosscountry transactions for the period from 1999 to 2002. In contrast with this work, we use annual data instead of average of a set of years as this provides a better understanding of the dynamic of fund transfers between countries. Another distinctive characteristic of our study is that it measures economic activity using a composite indicator of three variables that allows a more inclusive description of the reality. In addition, we study the impact of the EZ economic crisis on the transactions received by Portugal, and, finally, we measure the impact of the EZ membership.

1 TARGET2 component system is operated by the Bank of Portugal. 
This paper includes five more sections and conclusion. The second section makes a brief review of the literature. Section three comprises a short description of the evolution of the payment systems in Portugal. The fourth section provides a descriptive analysis of the data used. The fifth section presents the main results achieved by implementing the proposed GM, followed by the section that presents evidence of the influence of the EZ crisis in the financial transactions between countries. Finally, we present the main conclusions.

\section{LITERATURE REVIEW}

Gravity models are traditionally used to explain the international flow of goods and services, financial funds and migrants. Inspired by the Law of Gravitation, the first GMs explained bilateral exchanges based on two key variables: the economic size of countries (measured by GDP and population) and the distance between them (Frankel 1997). The underlying idea is that a mass of demand for goods at a destination point attracts a mass of goods at an origin point. Typically, these models take the form of:

$$
F_{i j}=g \frac{M_{i} M_{j}}{D_{i j}},
$$

where $\mathrm{F}_{\mathrm{ij}}$ is the volume of trade between country $i$ and country $j, g$ is a constant, $\mathrm{M}_{i}$ and $M_{j}$ are the economic dimensions of country $i$ and country $j$, respectively, usually represented by GDP, and $D_{i j}$ is the distance between countries $i$ and $j$. The variables measuring the economic size of countries are expected to have a coefficient of one; that is, constant $g$ should be one.

The GM applications include the influence of other variables on commercial transactions (e.g. Linnemann 1966; Deardorff 1998). Notably, Anderson (1979) was the first to study the effect of sharing a border.

Structural gravity models offer an economic theory of bilateral flows that takes into consideration the relative attractiveness of each country of origin/destination (Anderson 2011). These models assume trade separability (modularity), which allows the analysis of distribution costs to be isolated from the determination of demand or supply of goods in each country. Usually, trade separability also requires that distribution costs of goods are proportional to their costs of production.

The GMs for trade flows can be justified in three different ways: one from the demand side, another from the supply side, and the third based on discrete choice models (Anderson 2011). In the demand side approach, preferences are restricted in such a way that the demand substitution between classes of goods only occurs through aggregate price indexes. This restriction can be achieved by imposing 
identical preferences across countries and assuming that the expenditure function has a constant elasticity of substitution.

In the supply side models, the demand for goods by each country depends only on the supply side factors. These models assume consumption homogeneity, iceberg trade costs (i.e., proportional to traded volume), and Ricardian technology with random productivity shocks for each country and each good.

Finally, the discrete choice model postulates that an individual trader faces unobserved costs and benefits that determine trade flows. Under reasonable assumptions, the decision of bilateral trade can be modelled using a multinomial logit model, which yields a GM.

GMs have been applied to the trade of both goods and services, as well as to the transaction of financial assets. Martin - Rey (2004) developed a model of assets' trade that rationalises the use of a standard gravity equation, where the explanatory variables are a measure of economic dimension, equity market capitalisation, and trading costs. The derivation of the model uses three assumptions: the assets are imperfect substitutes due to differences in risk, the international trade of assets has transaction and/or information costs, and the supply of assets is endogenous.

Among the empirical approaches, Portes - Rey (2005) studied capital markets in Europe, USA and Asia, using a panel of 14 countries from 1989 to 1996, and concluded that the flow of gross assets depends on the size of both the issuing and recipient countries of transaction. Market sophistication, efficiency, technology and information also play an important role, and similarly distance has a strong and robust effect on cross-border transactions, due to information costs.

Portes et al. (2001) investigated the importance of information for foreign dealers of stocks, treasury bonds, and corporate bonds. They used the bilateral flows between the USA and 40 advanced and emerging markets from 1988 to 1998. The results support the hypothesis that asymmetries of information are responsible for the strong negative relationship between distance and transactions of companies' stocks and bonds, but distance has no influence on the negotiation of government bonds.

In a similar manner, Portes - Rey (2005) analysed the flow of capital between countries for a panel of 14 countries for the period from 1989 to 1996. These transactions are explained by the size of the market, efficiency of transaction technology and distance. The negative effect of distance is due to information asymmetries that fragment international markets.

Flavin et al. (2002) used a GM to explain the exchanges of financial assets (notably shares) and goods between 27 countries for 1999. They concluded that the geographical variables, language, and different accounting rules can be major barriers to those transactions. 
Loungani et al. (2002) showed that the study of foreign direct investment flows (FDI) can be modelled using the same gravity equation applied to trade flows. They applied a GM to shed light on the role played by distance in the flow of goods and FDI and found that although distance acts as a natural barrier, nations are becoming economically closer and information infrastructures foster greater proximity between them.

Aviat - Coeurdacier (2007) study the surprisingly large negative impact of distance on the trade of goods and financial flows in GMs. They conclude that distance is very important only for the trade of goods and that its effect almost vanishes when the trade of goods is introduced to explain exchange of assets.

Papaioannou (2009) conducted one of the first studies applying a GM to assess the role of political and institutional variables in the transnational movement of capital, and reached three main conclusions. First, considering "size" and distance, countries with higher quality institutions and less political risk trade more assets. Second, foreign banks prefer to extend credit to the countries that do not have corruption problems and where the legal system works effectively. Finally, bank lending was stimulated between the European countries through harmonised laws and policies on financial securities, and this lowers the foreign exchange risk.

The GMs have also been used, albeit less frequently, to understand interbank financial flows. Rosati - Secola (2006) showed that the interbank payments between TARGET2 countries in 1999-2002 were conditioned by various types of economic variables, as well as geographic proximity. In a market with the features of the EU, some of these variables, notably distance, should not be an obstacle to transactions.

There are other relevant studies that did not apply GMs. Admati - Pfleiderer (1988) show asset transactions are affected by liquidity and information, as well as by the existence of informed and uninformed traders.

Ciampolini - Rohde (2000) conducted a review of the EA interbank unsecured deposit segments and conclude that the national markets have a high degree of integration and organisation and liquidity flows efficiently. In addition, they found that the largest banks play an important role by regularly conducting crossborder transactions and their preferred partners are larger banks. The transactions of smaller banks are usually carried out within their own country. The market became more integrated after the adoption of a single currency because more transnational transactions were made and the number of counterparties involved increased. This work suggests that the larger countries have more transactions with other larger countries, as predicted by the GM.

Grinblatt - Keloharju (2001) studied the equity market in Finland and demonstrated that distance, culture and language are important when explaining trans- 
actions. The surprising significance of the geographical variables in financial transactions in a financially globalised and technological world is explained by information asymmetry (which can grow with distance) and trade links (that depend on transportation costs).

Pröpper et al. (2008) examined the structure of the Dutch system of large payments, TOP, which was a part of the TARGET. They show that the payment network was small and compact and its structure was not affected by the subprime crisis in 2007, despite showing some vulnerabilities.

Bech et al. (2008) studied the development of payment systems and found they are becoming increasingly efficient due to technological innovations; however, these, together with financial innovations and globalisation, intensified the need for system harmonisation, integration and consolidation.

In conclusion, the literature highlights several elements that affect capital flows. These are positively related to the size of the economies and negatively related to the distance between countries. Moreover, border effects, countries' institutional characteristics, market sophistication, efficiency and information technology also play an important role.

In this context, our paper focuses on the effects of distance, real GDP, financial variables, and financial crises on the amount of cross-border transactions of the TARGET2-PT system. The following hypotheses are tested: GDP and other variables measuring economic and financial dimensions have a positive effect on transactions received on the TARGET2-PT system (H1); Distance between countries negatively affects the amount of transactions (H2); Border sharing positively influences the amount of cross-border transactions (H3), and belonging to the EA positively affects the amount of cross-border transactions (H4).

\section{THE GROSS SETTLEMENT SYSTEMS IN THE EA}

\subsection{Implementation}

For transactions to flow quickly, efficiently and at a low cost between countries after the introduction of the Euro in 1999, a financial transactions infrastructure was developed - the TARGET - to which 15 EU central banks were linked on $4^{\text {th }}$ January 1999. This system contributed to a single and integrated monetary policy and the safe and efficient movement of funds in Euros between central bank accounts (ECB 2010). In 2007, the need arose to create a second-generation system, TARGET2. About a thousand commercial banks use this system to perform operations on their behalf or on behalf of their clients and the system connect about 
57 thousand banks. ${ }^{2}$ Overall, the system has daily transactions of about 2.5 trillion Euros, which is equivalent to a quarter of the EZ GDP. At the end of 2012, 23 EU countries participated in the system, including some countries out of the EZ.

In Portugal, a vast majority of the domestic credit institutions with an account in the Bank of Portugal (the Portuguese central bank) joined the TARGET2 system as direct participants. The national component of that system is operated by TARGET2-PT. The participants of the system are the ECB, the credit institutions established in the European Economic Zone, and a smaller number of credit institutions outside this area that access through a branch established in a national central bank of a Member State (Bank of Portugal 2010).

It is the Bank of Portugal that "regulates, oversees and promotes the proper functioning" of TARGET2. Many of its operations are between banks or between other participants in the financial markets; they are mostly the large amounts' operations and usually require an urgent settlement. In addition to the operations of large amounts, the system also includes retail operations and any other payments sent to the participants in the TARGET2.

\subsection{The economic importance of the TARGET system}

TARGET2 operations are subject to various risks: legal, settlement, credit, operational, and systemic. The latter can lead to the crash of the financial system as the failure of one entity may spread to other participants (Kokkola 2010). To mitigate these risks, the national central banks regulate the interbank payment systems.

All international operations in TARGET2 are somehow linked to the current, capital and financial accounts of the balance of payments. The TARGET2 system plays a central role in the ECB's monetary policy operations, notably in the control of both the economy's liquidity and the Interbank Money Market (IMM) interest rate, and therefore of all interest rates in the economy.

This system also facilitates the operation and integration of the EU IMM. If a country is affected by a negative asymmetric shock, TARGET2 helps to mitigate it through loans to that country. In addition, due to the monetary union and the absence of exchange rate risks, banks from various countries can benefit from the access to liquidity at lower interest rates. In conclusion, the TARGET2 system facilitates the functioning of central bank policy operations and of the IMM and plays an important role in stabilising the economy.

2 Source: http://www.ecb.europa.eu/paym/t2/html/index.en.html 


\section{CHARACTERISATION OF TARGET2-PT TRANSNATIONAL OPERATIONS}

In January 1999, there were only 15 countries in TARGET, but this number as we already mentioned, has steadily increased (Table 1). On the other hand, England abandoned the system when TARGET2 was created and the transactions with England are now made through other TARGET2 participants.

Turning to the transactions between Portugal and other countries, we analyse the weight of each country in relation to the total annual value of transactions. The figures are presented for 1999, 2006 and 2012. The year 2006 was chosen because it is the last full year of operations of the first system's generation and 2012 is the last year analysed herein.

In 2006, the six countries with the largest share of operations sent to Portugal via TARGET2 (Table A1 in Appendix) were, in descending order: Spain (with $20.3 \%$ of total transactions), Germany (16.4\%), France (12.6\%), Belgium (11.4\%), Italy (10.8\%) and England (10.7\%); these totalled $82.09 \%$ of the operations (Bank of Portugal). There was a change in profile in 2012 and most transactions come essentially from three countries, representing $81.3 \%$ of operations: Spain (40.9\%), Germany (26.1\%) and Belgium (14.3\%). There is a similar profile for operations sent from Portugal to other countries. ${ }^{3}$

In 2012, Luxembourg only represented $5 \%$ of the total funds received by Portugal, but the funds sent in proportion of its GDP are a large amount: $113 \%$ between 1999 and 2012, which compares with an average of 13.9\% for all countries. This probably results from Luxembourg's position as a financial centre, suggesting that the financial variables are important to describe the interbank flows.

The Eastern European countries, such as Bulgaria, Latvia, Lithuania, Poland, and Romania, located at a considerable distance from Portugal and outside the Eurozone (before 2012), sent a very small amount of funds to Portugal in proportion of their GDP: on average each country sent less than 0.5\% of GDP during the period under analysis.

Generally, the ratio between funds received by Portugal and GDP of the country sending them varies considerably across countries and time. This indicates factors other than GDP are at stake: distance, EZ membership, business cycle, and financial crises may play a significant role, as we detail in the next section.

Analysing each year, we observe that the weight of France and Italy in total operations began to decline from 2008. We suggest this may be related to the fall in exports to those countries and to the fact that the Italian banks began reducing lending to the Portuguese banks due to the difficulties associated with the European sovereign debt crisis.

3 Data are available upon request. 
Table 1. Historical evolution of the TARGET system

\begin{tabular}{|c|c|c|}
\hline Target phase & Time period & Countries or organisation \\
\hline \multirow[t]{5}{*}{ TARGET } & 1999/01/04 & $\begin{array}{l}\text { In: Austria, Belgium, Denmark, England, Finland, France, } \\
\text { Germany, Greece, Netherlands, Ireland, Italy, Luxembourg, } \\
\text { Portugal, Spain, Sweden, ECB }\end{array}$ \\
\hline & $2005 / 03 / 07$ & In: Poland \\
\hline & $2005 / 07 / 01$ & In: Slovenia \\
\hline & $2006 / 11 / 20$ & In: Estonia \\
\hline & $2006 / 12 / 31$ & Out: Sweden \\
\hline \multirow{2}{*}{$\begin{array}{l}\text { Transition } \\
\text { period between } \\
\text { TARGET and } \\
\text { TARGET2 }\end{array}$} & 2007/11/19 & $\begin{array}{l}\text { In TARGET2: Austria, Cyprus, Germany, Latvia, Lithuania, } \\
\text { Luxembourg, Malta, Slovenia }\end{array}$ \\
\hline & $2008 / 02 / 18$ & $\begin{array}{l}\text { In TARGET2: Belgium, Finland, France, Ireland, Nether- } \\
\text { lands, Portugal, Spain }\end{array}$ \\
\hline \multirow[t]{4}{*}{ TARGET2 } & $2008 / 05 / 19$ & $\begin{array}{l}\text { In: Denmark, Estonia, Greece, Italy, Poland, ECB } \\
\text { Out: England }\end{array}$ \\
\hline & 2009/01/02 & In: Slovakia \\
\hline & $2010 / 02 / 01$ & In: Bulgaria \\
\hline & $2011 / 07 / 04$ & In: Romania \\
\hline
\end{tabular}

As explained above, Portugal received funds from a small number of partners in 2012 (Germany, Belgium and Spain) and was therefore subject to a considerable level of risk. Figure 1 shows the evolution of these concentrations. Rosati - Secola (2006) also showed that many European countries carry out most of the operations with three participating countries, but the concentration is not as large as for Portugal.

In addition, Figure 2 shows the total value of cross-border transactions received and sent via TARGET2-PT from 1999 to 2012. The two series have a very similar profile, with a correlation of 0.996 . The upward trend in operations between 2000 and 2004 was followed by a downward trend from 2005 .

We use three economic variables to explain TARGET2 operations: real GDP (at 2005 prices) from the Eurostat, the aggregate balance sheet of the EZ Monetary Financial Institutions (MFIs) - BS hereinafter - obtained from the ECB, and Stock Market Capitalisation (SMC) from the World Bank. The last variable was converted from dollars to Euros using the US Federal Reserve exchange rates.

The geographical variables - distance (between capital cities) and the dummy for common border - were obtained from the database of GeoDist of the Centre d'Etudes Prospectives et d'Informations Internationales (CEPII) (Mayer Zignago 2011). Finally, the dummy indicating a country's EA membership was obtained from the ECB website. The descriptive statistics of all variables used can be found in Table A2 in the Appendix. 


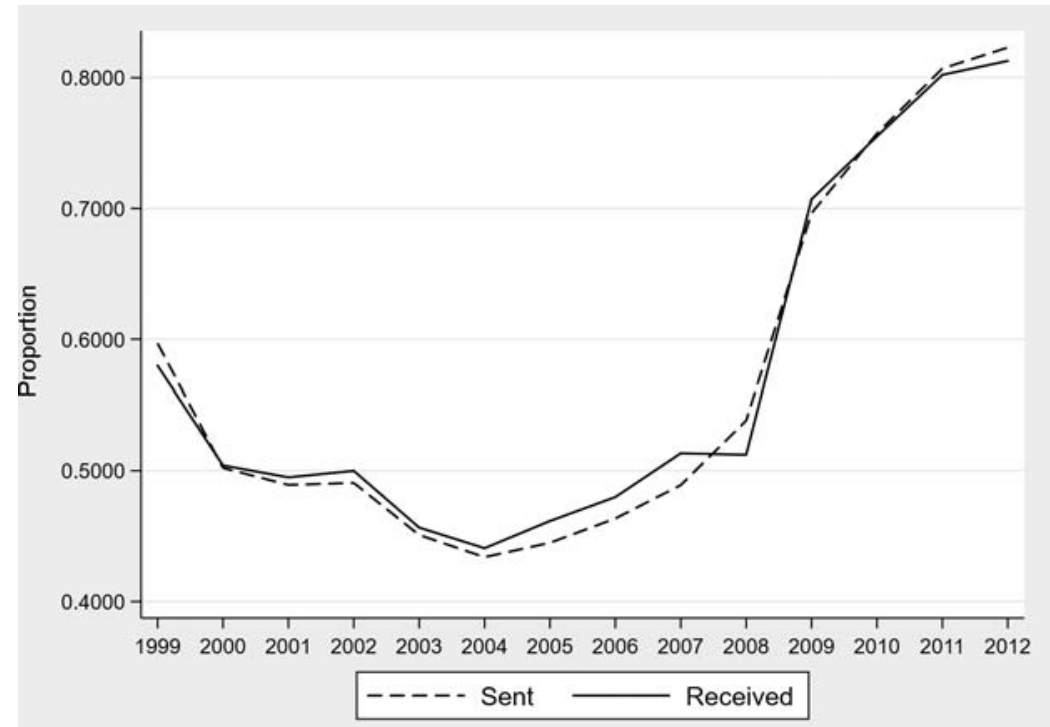

Figure 1. Weight of operations from Germany, Belgium and Spain

Source: Elaborated by the authors with data provided by the Bank of Portugal.

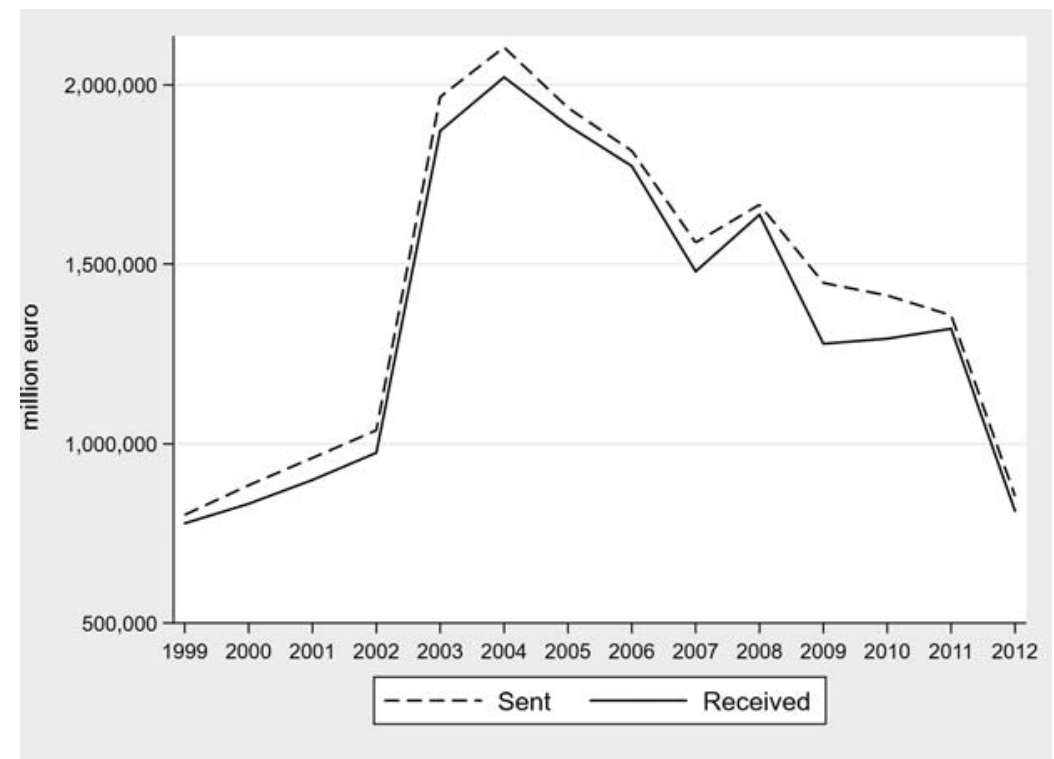

Figure 2. Total of transnational operations sent to and received by Portugal (million euro) Source: Elaborated by the authors with data provided by the Bank of Portugal. 


\section{EMPIRICAL MODELLING OF TRANSNATIONAL OPERATIONS}

\subsection{Model estimation: first results}

In this section, we estimate a GM for the volume of operations received in TARGET2-PT during 1999-2012. We only use the incoming operations because our goal is to study the financing of the Portuguese economy. Nevertheless, the received and sent operations have a strong correlation, as seen above.

The model employs the usual explanatory variables: real GDP, distance, and a dummy variable for common border. Two financial variables are used as alternatives to GDP: Stock Market Capitalisation (SMC) and aggregate balance sheet of Eurozone MFIs (BS) ${ }^{4}$, which are used to characterise the size of the financial market and the banking sector, respectively (Rosati - Secola 2006). Finally, we incorporate a dummy variable to capture whether a country is a member of the EZ.

To test the hypotheses described in Section 2, we start with the following model:

$$
\ln \left(R_{j, t}\right)=\beta_{0}+\beta_{1} \ln \left(G D P P_{t} G D P_{j, t}\right)+\beta_{2} D_{j}+\beta_{3} B_{j}+\beta_{4} E A_{t, j}+\varepsilon_{j, t},
$$

where $R_{j, t}$ - Operations received by Portugal from country $j$ in year $t, G D P P_{t}$ - Real GDP of Portugal in year $t, G D P_{j, t}$ - Real GDP of country $j$ in year $t, D_{j}-$ Physical distance between Portugal and country $j, B_{j}$ - Dummy variable that takes value 1 if country $j$ borders Portugal and zero otherwise ${ }^{5}, E A_{t, j}$ - Dummy variable that takes value 1 if country $j$ is integrated in the EA in year $t$, and zero otherwise, $\varepsilon_{j, t}$ - Random error.

Using OLS and standard errors robust to heteroscedasticity and correlation of errors over time for a country (cluster by country), we conclude that GDP has a positive and statistically significant effect on the reception of cross-border operations in Portugal via TARGET2 (Table 2, second column). The estimated elasticity is 1.26 , that is, if the GDP of Portugal or of its partners increases by $1 \%$, transactions increase by $1.26 \%$. Thus, GDP elasticity is larger than that obtained for all countries of TARGET-system by Rosati - Secola (2006) - 0.95. One possible reason for this may be the high degree of openness of the Portuguese economy and its significant dependence on external funding. For the remaining variables,

$4 \quad$ Due to missing data on the Aggregate balance sheet of MFIs for Denmark in 1999 and Sweden in 1999 and 2000, in these cases we used the values for the Aggregate balance sheet of Other Monetary Financial Institutions (OMFIs) obtained from the Eurostat. The difference between these data is that the central bank is included in the former and not in the latter.

As Portugal only has frontier with Spain, the variable $B$ indicates the fixed effect for Spain. 
we highlight the positive effect of EZ membership on transactions (significant at $10 \%)$.

To our surprise, our results indicate that distance is not statistically significant to explain the funds received, raising doubts on the validity of the gravitational model, where a key element is the distance between countries. This leads us to a model with fewer restrictions, in which the GDP of both Portugal and the partner countries have a different regression coefficient. The second round of estimations confirm that the gravitational model is not the best, as the coefficients of the GDP variables are very distinct: the GDP of Portugal is not statistically significant, whereas that of partner countries is, with a coefficient of 1.26 (Table 2, third column). Moreover, distance remains a non-significant variable.

The regression with SMC yields similar results; both the dummy for EZ membership $E A_{j}$ and the SMC of partner countries are significant (with an elasticity

Table 2. Regression with several indicators of economic activity

\begin{tabular}{|c|c|c|c|c|c|}
\hline & GDP & GDP & SMC & BS & BS \\
\hline & \multicolumn{5}{|c|}{ Coefficient (Stand. errors) } \\
\hline $\begin{array}{l}\ln (G D P P t \\
G D P j, t)\end{array}$ & $\begin{array}{l}1.2643 * * * \\
(0.3177)\end{array}$ & - & - & - & - \\
\hline $\ln \left(G D P P_{f}\right)$ & 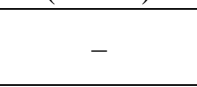 & $\begin{array}{l}-0.4760 \\
(3.0171)\end{array}$ & - & - & - \\
\hline $\ln \left(G D P_{j, \nu}\right)$ & - & $\begin{array}{l}1.2627 * * * \\
(0.3164)\end{array}$ & - & - & - \\
\hline $\ln (S M C P)$ & - & - & $\begin{array}{l}-0.0910 \\
(0.3734)\end{array}$ & - & - \\
\hline $\ln \left(S M C_{j,}\right)$ & - & - & $\begin{array}{l}1.1754^{* * *} \\
(0.1654)\end{array}$ & - & - \\
\hline $\ln (B S P)$ & - & - & - & $\begin{array}{l}-2.9666 * * * \\
(0.5870)\end{array}$ & $\begin{array}{c}-1.1160^{*} \\
(0.5382)\end{array}$ \\
\hline $\ln \left(B S_{j, t}\right)$ & - & - & - & $\begin{array}{l}1.5603^{* * * *} \\
(0.1973)\end{array}$ & $\begin{array}{l}1.5450^{* * *} \\
(0.1948)\end{array}$ \\
\hline$D_{j}$ & $\begin{array}{l}-0.00080 \\
(0.00060)\end{array}$ & $\begin{array}{l}-0.00080 \\
(0.00060) \\
\end{array}$ & $\begin{array}{l}-0.00042 \\
(0.00043) \\
\end{array}$ & $\begin{array}{c}0.00037 \\
(0.00048) \\
\end{array}$ & $\begin{array}{c}0.00036 \\
(0.00048) \\
\end{array}$ \\
\hline $\boldsymbol{B}_{j}$ & $\begin{array}{l}-0.3625 \\
(1.0157) \\
\end{array}$ & $\begin{array}{l}-0.3584 \\
(1.0147) \\
\end{array}$ & $\begin{array}{l}-0.1309 \\
(0.7642) \\
\end{array}$ & $\begin{array}{l}1.7148^{* *} \\
(0.7914)\end{array}$ & $\begin{array}{l}1.6966^{* *} \\
(0.7848)\end{array}$ \\
\hline$E A_{t, j}$ & $\begin{array}{c}1.3560^{*} \\
(0.7449)\end{array}$ & $\begin{array}{c}1.3669^{*} \\
(0.7490)\end{array}$ & $\begin{array}{l}1.5511^{* *} \\
(0.6530)\end{array}$ & $\begin{array}{l}1.3818^{* *} \\
(0.6006)\end{array}$ & $\begin{array}{l}1.3805^{* *} \\
(0.5947)\end{array}$ \\
\hline DCrisis $_{t}$ & - & - & - & - & $\begin{array}{l}-1.1324 * * * \\
(0.2064)\end{array}$ \\
\hline Cons & $\begin{array}{c}-20.4900 * * \\
(9.0295)\end{array}$ & $\begin{array}{c}0.2965 \\
(35.7815)\end{array}$ & $\begin{array}{c}-3.5173 \\
(4.3236)\end{array}$ & $\begin{array}{l}24.6834^{* * * *} \\
(7.3828)\end{array}$ & $\begin{array}{c}1.5739 \\
(7.1932)\end{array}$ \\
\hline $\mathrm{N}$ & 220 & 220 & 220 & 220 & 220 \\
\hline $\mathrm{R} 2$ & 0.6168 & 0.6171 & 0.7085 & 0.642 & 0.7532 \\
\hline
\end{tabular}

Note: Robust standard errors are in parenthesis. $* * *$ significant at $1 \%$, ** 5\%, and * $10 \%$, respectively. 
of 1.17), but the SMC of Portugal does not significantly affect financial transfers (Table 2, fourth column).

Finally, the regression performed with the MFI balance sheet indicates that this variable for the partner countries is statistically significant and has a positive impact on the received cross-border transactions (Table 2, fifth column); it showed the largest elasticity: 1.56 . Strangely, the size of the MFI balance sheet in Portugal has a negative effect (-2.96) on received funds. To verify the robustness of this result, we introduced a dummy variable, DCrises, with value one from 2007 onwards, to capture the effect of the crises. The balance sheet of Portuguese banks continues to exert a negative impact on transactions, but now with a p-value of only $10 \%$ (Table 2, sixth column). Although the result does not have a very high statistical significance and does not hold in the next regressions, it may express the fact that when the financial sector was growing rapidly it was able to obtain financing outside the EZ and this inflow of capital was not registered through the TARGET system.

There are two additional observations from the last regression. Firstly, it is noticed that the regression with BS (and with no crisis dummy) has the largest R-squared; this is expected to occur in Europe where the financial system is bankbased. Secondly the crisis dummy indicates that during the economic downturn transactions fell 67.6\% vis-à-vis the 1999-2006 period.

The GDP, BS or SMC variables can all be introduced in the same regression rather than one at a time, as done above. Before doing this, we assess the existence of multicollinearity by computing the correlations between the variables. ${ }^{6}$ We found that the variables $\ln \left(G D P_{j, t}\right), \ln \left(S M C_{j, t}\right)$ and $\ln \left(B S_{j, t}\right)$ have correlations larger than 0.8 , indicating the presence of multicollinearity.

We then conduct further tests to confirm multicollinearity using the indicator Variance Inflation Factor $(V I F)$, which cannot exceed $1 /\left(1-\mathrm{R}^{2}\right)$, where $\mathrm{R}^{2}$ is the regression with all variables (0.7819). A tolerance indicator smaller than $\left(1-\mathrm{R}^{2}=0.2181\right)$ also shows multicollinearity. The VIF test for GDP, SMC and BS is larger than $1 /\left(1-\mathrm{R}^{2}\right)=4.58$, indicating there is multicollinearity for those variables. ${ }^{7}$ The same conclusion can be reached using the tolerance indicator.

Given the impossibility of simultaneously including the three variables measuring economic activity, we carry out a Principal Component Analysis (PCA) of these variables to create synthetic indicators of economic activity for Portugal and for the set of partner countries. 


\subsection{Model with a single indicator of economic activity}

We will transform the three variables of economic activity into one or two variables. PCA is used to identify the components that capture the maximum characteristics shared by the original variables expressed in logs.

The first component for the partner countries $\left(C 1_{j, t}\right)$ captures $91.34 \%$ of the variability of the three variables. In addition, this component has positive loadings on all variables. For Portugal, the first component (named $C 1 P_{t}$ ) only explains $58.42 \%$ of the variability and has small loadings on SMC. Although with an eigenvalue less than 1 (but very close to 1, 0.9906), a second factor (named $C 2 P_{t}$ ) was extracted to better describe the stock market movement in Portugal.

Therefore, we replace the variables; GDP, SMC and BS with the principal components, and the model becomes:

$$
\ln \left(R_{j, t}\right)=\beta_{0}+\beta_{1} C 1 P_{t}+\beta_{2} C 2 P_{t}+\beta_{3} C 1_{j, t}+\beta_{4} D_{j}+\beta_{5} B_{j}+\beta_{6} E A_{t, j}+\varepsilon_{j, t} .
$$

This new model allows us to conclude that the first component for the partner countries and for Portugal and also $E A_{t, j}$ have a positive and statistically significant effect on transnational operations received through TARGET2-PT (Table 3, second column). It is relevant that the elasticity of variable $C 1_{j, t}$ is smaller than that of BS but greater than that of GDP and SMC. This result probably stems from the fact that $C 1_{j, t}$ represents the three variables. Finally, distance and border did not prove to be significant; this contradicts the results of Rosati - Secola (2006), namely, that these variables play an important role in transnational flows.

The literature argues that the physical distance and "not sharing" a border can be taken as proxies of information asymmetry. However, our study concludes that these variables are not relevant, which is reasonable given the fact that the EU is a commercially and financially integrated area with a large flow of information between the countries. Systems such as TARGET2 aim to make exchanges more efficient and help remove geographical and informational barriers to financial operations.

Finally, the statistical significance and positive sign of EZ membership may be related to the absence of an exchange rate risk between the countries in this area, which results in a greater volume of financial transactions. Alternatively, it could be associated to the institutional characteristics that limit widespread access to TARGET2 by the banks outside of the EZ.

The pairs of countries and years for which the model does not perform so well (that is, the residual is larger than twice the residual standard deviation) are concentrated in the crisis years of 2011 and 2012; and in Ireland, a country directly 
Table 3. Regression with synthetic components of economic activity and with interest rates

\begin{tabular}{|c|c|c|c|}
\hline & Principal components & With fixed effects & TB interest rates \\
\hline Variable & \multicolumn{3}{|c|}{ Coefficient (Stand. error) } \\
\hline$C 1 P_{t}$ & $\begin{array}{l}0.3955^{* * *} \\
(0.0811)\end{array}$ & \begin{tabular}{|c|}
$0.4994^{* * *}$ \\
$(0.1405)$ \\
\end{tabular} & $\begin{array}{l}0.2198^{* *} \\
(0.1036)\end{array}$ \\
\hline$C 2 P_{t}$ & $\begin{array}{c}0.1224 \\
(0.0812) \\
\end{array}$ & $\begin{array}{c}0.1074 \\
(0.0762) \\
\end{array}$ & $\begin{array}{l}-0.0574 \\
(0.0662) \\
\end{array}$ \\
\hline$C 1 P_{t, j}$ & $\begin{array}{l}1.2805^{* * *} \\
(0.1854)\end{array}$ & $\begin{array}{l}-0.5624 \\
(0.8063)\end{array}$ & $\begin{array}{l}-0.0103 \\
(0.8602)\end{array}$ \\
\hline $\ln \left(T B P_{t}\right)$ & - & - & $\begin{array}{l}-1.2415^{* *} \\
(0.4790)\end{array}$ \\
\hline $\ln \left(T B_{t, j}\right)$ & - & - & $\begin{array}{l}-0.1900 \\
(0.6431)\end{array}$ \\
\hline$D_{j}$ & $\begin{array}{c}-0.00018 \\
(0.00042)\end{array}$ & - & - \\
\hline$B_{j}$ & $\begin{array}{c}0.4842 \\
(0.7912)\end{array}$ & - & - \\
\hline$E A_{t, j}$ & $\begin{array}{l}1.4394 * * \\
(0.5908)\end{array}$ & $\begin{array}{l}3.3909 * * * \\
(0.1711)\end{array}$ & $\begin{array}{l}3.4616 * * * \\
(0.1935)\end{array}$ \\
\hline DCrises $_{t}$ & $\begin{array}{l}-1.9692 * * * \\
(0.3424)\end{array}$ & $\begin{array}{l}-1.2990 * * * \\
(0.4103)\end{array}$ & $\begin{array}{l}-0.5095^{*} \\
(0.2848)\end{array}$ \\
\hline Cons & $\begin{array}{l}\text { 9.698*** } \\
(1.2269)\end{array}$ & $\begin{array}{l}7.7129 * * * \\
(0.3086)\end{array}$ & $\begin{array}{l}9.5653^{* * *} \\
(1.4197)\end{array}$ \\
\hline \multirow[t]{2}{*}{ Country fixed effects } & No & Yes & Yes \\
\hline & $\mathrm{N}=220 . \mathrm{R}^{2}=0.7535$ & $\begin{array}{l}\mathrm{N}=220 \\
\mathrm{R}^{2} \text { (overall) }=0.0146 \\
\mathrm{R}^{2} \text { (within) }=0.2621 \\
\mathrm{R}^{2} \text { (between) }=0.0066\end{array}$ & $\begin{array}{l}\mathrm{N}=220 \\
\mathrm{R}^{2} \text { (overall) }=0.1603 \\
\mathrm{R}^{2} \text { (within) }=0.3387 \mathrm{R}^{2} \\
\text { (between) }=0.2506\end{array}$ \\
\hline
\end{tabular}

Note: Robust standard errors are in parenthesis. ${ }^{* * *}$ significant at $1 \%, * * 5 \%$, and $* 10 \%$, respectively.

affected by the crisis, and some Eastern European countries (Bulgaria, Lithuania, Slovakia, and Slovenia) in these years.

The structural gravity models include elements of unobserved multilateral resistance, which measure the average bilateral trade costs of countries to all trading partners, allowing to capture the third-party effects on bilateral trade. These elements are usually captured by estimating a fixed effect model, with fixed effects for the importer and the exporter.

We capture the third-party effects by introducing fixed effects only for the exporters of capital. No fixed effects for importers are considered because there is only one importer: Portugal. In this new formulation, where the time constant variables (frontier and distance) were dropped, the most notable change in the results is that the economic activity component of partners becomes statistically 
insignificant (Table 3, third column). The significance of this variable declined probably because the fixed effects capture the impact of the economic dimension of the partner countries, which is relatively stable in the short run. Alternatively, the larger countries may incur fewer costs (essentially information costs) in the transaction of funds. This may explain why the positive and significant impact of partner countries' economic size disappears once the transaction costs are introduced in the model by means of fixed effects.

\section{THE EFFECT OF THE EUROZONE CRISIS ON TARGET FLOWS}

The European sovereign debt crisis was due to structural weaknesses in some countries (notably loss of competitiveness and poor credit standards - Daianu 2012) and governments led actions to alleviate the effects of the subprime crisis (in terms of banks' support and aggregate demand). The subprime crisis started in the US and spread to Europe as high-risk marketable products related with the US subprime market were acquired by the European institutions, which subsequently encountered difficulties, liquidity problems and had to be redeemed by the governments. The ECB provided extensive liquidity provision and accepted various types of collateral so that banks could adjust their balance sheets. Access to bonds market started to become more restricted in some peripheral countries as the interest rates of treasury bonds soared and, ultimately, they were forced to request financial assistance: Greece on $2^{\text {nd }}$ May 2010, followed by Ireland on $28^{\text {th }}$ November 2010 and Portugal on $17^{\text {th }}$ May 2011. Although there were interventions in Spain and Cyprus, they were not so extensive as in the afore-mentioned countries.

The dummy to capture the effect of the crises during 2007-2012 on crossborder transactions received by Portugal already indicated a strong impact. The effect of the economic downturn was particularly strong because of the sharp growth in credit with external financing between 1995 and 2006 (Mamede et al. 2016), referred to as a credit boom by some authors (e.g. Lane 2012). We furthered our analysis of this issue by redesigning the model and adding variables that characterise the crisis period, more specifically, the 10-year interest rate on the Portuguese Treasury bonds, $T B P_{t}$ and the 10-year interest rate of treasury bonds of the partner countries, $T B_{j, t}$. The addition of these two variables allows us to assess the impact of country risks on financial flows. During the crisis, Portugal's treasury bonds yields and those of other EZ countries rose considerably due to the increase in default risk.

However, the effect of $T B P_{t}$ and $T B_{j, t}$ on the flows received by Portugal is, $a$ priori, ambiguous. Keeping other interest rates constant, an increase in the Por- 
tuguese treasury bonds yields represents a greater risk of Portugal's default: this implies a reduction in loans to the country and a decrease in the inflow of investment. In addition, the Portuguese financial institutions and firms may repatriate funds by disinvesting in other countries to finance the domestic activities, for which it is more difficult to obtain market financing.

An increase in a partner country's risk means that the Portuguese investors will withdraw funds from that country, increasing the received flows. But this country will also decrease investments and loans to Portugal. Thus, the interest rate of a partner country has an uncertain effect on the flows received by Portugal.

As Portugal was a net receiver of external financing, the predominant effect of an increase in its country risk will be a reduction in funds received from across the border, and the main effect of a rise in the partner's risk will be a reduction in funds sent to Portugal. Thus, the hypothesis to test is that the 10 -year government bond yields of Portugal and of partner countries negatively affect the amount of received transactions through TARGET2-PT (H5).

The initial model is re-formulated as:

$$
\begin{gathered}
\ln \left(R_{j, t}\right)=\beta_{0}+\beta_{1} C 1 P_{t}+\beta_{2} C 2 P_{t}+\beta_{3} C 1_{j, t}+ \\
+\beta_{4} \ln \left(T B P_{t}\right)+\beta_{5} \ln \left(T B_{j, t}\right)+\beta_{6} E A_{t, j}+u_{j}+\varepsilon_{j, t},
\end{gathered}
$$

where $T B P_{t}-10$-year Portuguese treasury bonds yield in year $t, T B_{j, t}-10$-year treasury bonds yield of partner country $j$ in year $t$, - exporter of funds fixed effect.

The summary statistics of the interest rates obtained from the ECB are found in Table A2 in the Appendix. In Table 3 (fourth column) we can confirm that the interest rate for Portugal has a negative and statistically significant effect on the dependent variable, confirming the negative influence of the crisis on the transnational flow of funds. It should be noted that the coefficient of the crises dummy goes down from -1.96 to -0.50 , and its statistical significance declines. Both changes suggest that the effect of the crisis is well captured by the country risk. The interest rate of partner countries is not statistically significant, maybe because it has contradictory impacts on the received funds, as seen above.

The effect of the crisis can also be analysed by adding year dummies on eq. (4), to capture economic events that affected the flow of funds received from all countries. In this model, we dropped the two variables of Portuguese economic activity because they conflict with the time dummies - both variables are equal for all countries in a given year.

Once again, we find that the variable $C 1_{\mathrm{j}, \mathrm{t}}$ is not statistically significant and the Eurozone dummy has a positive and statistically significant effect on the flow of funds (Table 4). The dummies between 2001 and 2005 indicate economic events with positive effects (relative to the base year) in the operations received from all 
countries. The dummies cease to be statistically significant from 2007, indicating specific events in those years reduced the amount of interbank flows to Portugal relative to the period between 2001 and $2005 .{ }^{8}$ Comparing the dummy year of 2006 with each dummy for the years 2007 to 2012, only that of 2012 stands out as statistically different; this allows us to conclude there was a significant decline in flows in this year relative to $2006(-197.4 \%)^{9}$, for reasons not controlled for by the explanatory variables. In our view, these are linked to the Subprime and European sovereign debt crisis.

It is interesting to analyse the operations Portugal received during the crisis from Germany and other countries that were most affected by the sovereign debt crisis. We choose to detail the impact of Germany because it is the most important country of the EZ; and we also included countries that benefited from financial assistance in this period, namely Cyprus, Spain, Greece and Ireland.

Table 4. Regression with year dummies

\begin{tabular}{l|c|c|c|c|c}
\hline Variable & $\begin{array}{c}\text { Coefficient } \\
\text { (Stand. error) }\end{array}$ & Variable (Year) & $\begin{array}{c}\text { Coefficient } \\
\text { (Stand. error) }\end{array}$ & Variable (Year) & $\begin{array}{c}\text { Coefficient } \\
\text { (Stand. error) }\end{array}$ \\
\hline$C 1_{j, t}$ & $\begin{array}{c}0.1103 \\
(1.0383)\end{array}$ & 2003 & $\begin{array}{c}1.1427^{* * *} \\
(0.2145)\end{array}$ & 2009 & 0.6014 \\
\hline$E A_{t, j}$ & $\begin{array}{c}3.4336^{* *} \\
(0.2183)\end{array}$ & 2004 & $\begin{array}{c}1.1174^{* * *} \\
(0.2652)\end{array}$ & 2010 & $\begin{array}{c}0.4332) \\
(0.4124)\end{array}$ \\
\hline Cons & $\begin{array}{l}6.5975^{* * *} \\
(0.0497)\end{array}$ & 2005 & $\begin{array}{c}1.0704^{* * *} \\
(0.3735)\end{array}$ & 2011 & -0.3500 \\
& $\begin{array}{l}0.1996^{* *} \\
(0.0920)\end{array}$ & 2006 & $\begin{array}{c}0.9252^{*} \\
(0.4466)\end{array}$ & 2012 & -0.6014 \\
\hline Y2000 & $0.2527^{* *}$ & 2007 & $\begin{array}{c}0.7192 \\
(0.5123)\end{array}$ & & $(0.6101)$ \\
\hline Y2001 & $(0.1062)$ & & $\begin{array}{l}0.5279 \\
(0.4781)\end{array}$ & & \\
\hline Y2002 & $0.3420^{* *}$ & 2008 & & & \\
\hline
\end{tabular}

Country fixed effects, $\mathrm{N}=220$

$\mathrm{R}^{2}$ (overall) $=0.2402 . \mathrm{R}^{2}$ (within) $=0.3587 . \mathrm{R}^{2}$ (between) $=0.3444$

Note: Basic year is 1999. Robust standard errors are in parenthesis. *** significant at $1 \%$, ** 5\%, and * $10 \%$, respectively.

8 We expect the introduction of TARGET2 in 2007 to have had a small positive impact on the cross-border transfers of funds because it represented an improvement in the settlement system. This implies that the effect of the crises would have been greater under the old TARGET system. Therefore, the empirical results we obtain slightly underestimate the effect of the crises on flows.

9 The change in 2012 relative to the base year of 1999 is exp $(-0.6014)-1=-0.4519$. The change in 2006 relative to the base year is exp $(0.9252)-1=1.5223$. Thus, the change between 2012 and 2006 was $-197.4 \%$. 
We interact the dummy variable of each country with the year dummies. For example, the German case has the interaction term: Germany*"Year t", with Germany as a dummy variable that takes value 1 when transactions are received from Germany. The year dummies take the value 1 in the respective year $t$. We have also chosen to study the interaction with year dummies for 2007 to 2012 as the Subprime and European debt crises were felt most acutely in these years. This implies that we introduce six interaction terms for Germany and other selected countries, totalising 30 terms. As an example, the variable, "Germany 2010" in Table 5 is equal to Germany* "Year 2010".

Regarding the coefficient of Year 2010, we can see that the interaction terms (Cyprus* "Year 2010" (1.17), Germany* "Year 2010" (0.79), Spain* "Year 2010" (1.20), Greece* "Year 2010” (1.79)) have a positive sign and are statistically sig-

Table 5. Regression with interaction between time dummies and selected country dummies

\begin{tabular}{|c|c|c|c|c|c|c|c|}
\hline Variable & Coeff. & Variable & Coeff. & Variable & Coeff. & Variable & Coeff. \\
\hline$C 1_{j, t}$ & $\begin{array}{c}0.1355 \\
(0.1 .1292) \\
\end{array}$ & Y2009 & $\begin{array}{c}0.3675 \\
(0.4175) \\
\end{array}$ & Сур 2010 & $\begin{array}{l}1.1783^{* *} \\
(0.4378)\end{array}$ & Gre 2009 & $\begin{array}{l}1.3778^{* * * *} \\
(0.3607) \\
\end{array}$ \\
\hline$E A_{t, j}$ & $\begin{array}{l}2.6987^{* * *} \\
(0.2000)\end{array}$ & Y2010 & $\begin{array}{c}0.2026 \\
(0.4068)\end{array}$ & Сур 2011 & $\begin{array}{c}-1.2259 * \\
(0.6704)\end{array}$ & Gre 2010 & $\begin{array}{l}1.7998 * * * \\
(0.2779)\end{array}$ \\
\hline Y2000 & \begin{tabular}{|c|}
$0.1982 * *$ \\
$(0.0920)$
\end{tabular} & Y2011 & $\begin{array}{c}-0.3424 \\
(0.5897)\end{array}$ & Сур 2012 & $\begin{array}{c}-1.5494 \\
(0.8413)\end{array}$ & Gre 2011 & $\begin{array}{l}2.1058 * * * \\
(0.6173)\end{array}$ \\
\hline Y2001 & \begin{tabular}{|c|}
$0.3039 * *$ \\
$(0.1173)$
\end{tabular} & Y2012 & $\begin{array}{c}-0.4974 \\
(0.6706)\end{array}$ & Spa 2007 & $\begin{array}{c}0.1026 \\
(0.2372)\end{array}$ & Gre 2012 & $\begin{array}{l}1.7663^{* *} \\
(0.6724)\end{array}$ \\
\hline Y2002 & \begin{tabular}{|c|}
$0.3951 * *$ \\
$(0.1550)$
\end{tabular} & Ger 2007 & \begin{tabular}{|c}
-0.1183 \\
$(0.1839)$
\end{tabular} & Spa 2008 & $\begin{array}{c}0.5603 \\
(0.4347)\end{array}$ & Ire 2007 & $\begin{array}{l}-0.7092 * * * \\
(0.1979)\end{array}$ \\
\hline Y2003 & $\begin{array}{l}1.1935^{* * *} \\
(0.2353)\end{array}$ & Ger 2008 & $\begin{array}{c}0.5247 \\
(0.4260)\end{array}$ & Spa 2009 & $\begin{array}{c}0.6988 \\
(0.5775)\end{array}$ & Ire 2008 & $\begin{array}{c}-0.3533 \\
(0.3780)\end{array}$ \\
\hline Y2004 & \begin{tabular}{|l|}
$1.1658 * * *$ \\
$(0.2903)$ \\
\end{tabular} & Ger 2009 & $\begin{array}{c}0.7349 * \\
(0.3586) \\
\end{array}$ & Spa 2010 & $\begin{array}{l}1.2035^{* *} \\
(0.4310)\end{array}$ & Ire 2009 & $\begin{array}{c}-0.3562 \\
(0.3848) \\
\end{array}$ \\
\hline Y2005 & \begin{tabular}{|l|}
$1.1155^{* * *}$ \\
$(0.4302)$ \\
\end{tabular} & Ger 2010 & $\begin{array}{r}0.7908 * * * \\
(0.0 .2648) \\
\end{array}$ & Spa 2011 & $\begin{array}{l}1.9610 * * * \\
(0.4715)\end{array}$ & Ire 2010 & $\begin{array}{c}-0.7835^{* * * *} \\
(0.2646)\end{array}$ \\
\hline Y2006 & \begin{tabular}{|c|}
$0.9673 *$ \\
$(0.5031)$ \\
\end{tabular} & Ger 2011 & $\begin{array}{l}1.2271^{* *} \\
(0.4598)\end{array}$ & Spa 2012 & $\begin{array}{c}1.5485^{* *} \\
(0.5577) \\
\end{array}$ & Ire 2011 & $\begin{array}{l}-4.0619 * * * \\
(0.4256)\end{array}$ \\
\hline Y2007 & \begin{tabular}{|c|}
0.7952 \\
$(0.5268)$ \\
\end{tabular} & Ger 2012 & $\begin{array}{c}0.9348^{*} \\
(0.5394) \\
\end{array}$ & Gre 2007 & $\begin{array}{c}0.2695 \\
(0.1716) \\
\end{array}$ & Ire 2012 & $\begin{array}{l}-4.6258^{* * *} \\
(0.5265)\end{array}$ \\
\hline Y2008 & $\begin{array}{c}0.4091 \\
(0.5358)\end{array}$ & Сур 2009 & $\begin{array}{l}1.8204 * * * \\
(0.4397)\end{array}$ & Gre 2008 & $\begin{array}{l}1.5781 * * * \\
(0.3828)\end{array}$ & Cons & $\begin{array}{c}\text { 7.1414*** } \\
(0.08075)\end{array}$ \\
\hline
\end{tabular}

Country fixed effects, $\mathrm{N}=220$

$\mathrm{R}^{2}$ (overall) $=03529 . \mathrm{R}^{2}$ (within) $=0.6005 . \mathrm{R}^{2}$ (between $)=0.4406$

Note: Y: year, Ger: Germany, Cyp: Cyprus, Spa: Spain, Gre: Greece, Ire: Ireland. Base year is 1999. Robust standard errors are in parenthesis. ${ }^{* * *}$ significant at $1 \%, * * 5 \%$, and $* 10 \%$, respectively. 
nificant. ${ }^{10}$ This tells us that, in 2010, there were specific factors for these countries not related to the independent variables and this explains why they sent more funds to Portugal (relative to the base year) than the other countries.

Based on the coefficient of the interaction term Germany * "Year 2011" (1.22), we can say that in 2011 and relative to other countries not affected by the sovereign debt crisis $^{11}$, Germany sent more funds to Portugal than would be expected given the characteristics of year 2011. Note that the same occurred for Spain (1.96) and Greece (2.10), but the received funds from Ireland (-4.06) and Cyprus $(-1.22)$ decreased more. Finally, the interaction terms in 2012 for Spain (1.54), Greece (1.76) and Ireland (-4.62) allow similar conclusions to be reached as those for 2011.

In conclusion, contrary to what would be expected, in 2010, 2011 and 2012 the years of the strongest impact of the European sovereign debt crisis - there was a more positive trend in the funds received from Germany, Spain and Greece than from other countries, and fewer funds were received from Ireland. These findings may be explained, for example, by the withdrawal of Portuguese funds from the most affected countries, Spain and Greece. However, we also wanted to confirm the influence of exports of goods and services to these countries, as this has a correlation of 0.8975 with the funds received by Portugal. Using the annual growth rate of exports of goods and services from Portugal to the five chosen countries, we confirm that the above results may be explained, in part, by improved exports (Table 6).

Table 6. Growth rate of exports of goods and services, to 6 partner countries (\%)

\begin{tabular}{|c|c|c|c|c|c|c|c|c|c|}
\hline & 2009 & 2010 & 2011 & 2012 & & 2009 & 2010 & 2011 & 2012 \\
\hline Germany & -17.8 & 13.3 & 14.0 & -4.7 & Greece & -20.0 & 4.4 & 16.3 & 17.6 \\
\hline Cyprus & -3.0 & 4.6 & -30.8 & -16.4 & Ireland & -27.0 & 0.4 & 17.6 & -2.7 \\
\hline Spain & -23.0 & 11.5 & 5.0 & -5.8 & EA & -17.8 & 11.9 & 10.5 & -2.1 \\
\hline
\end{tabular}

Source: Elaborated by the authors with data from Bank of Portugal.

The rise in incoming transactions from Germany in 2010 and 2011 and Greece in 2011 and 2012 can be partly explained by a higher growth in Portuguese exports to these countries than to the EA. However, other events may have triggered this increase in flows from Greece, notably the divestment of the Millennium BCP (a top Portuguese Bank) in Greece. In addition, the fall in flows received in 2010 from Ireland and in 2011 from Cyprus can be partly explained by exports. For the remaining countries affected by the crisis, exports do not explain the in-

10 We analysed only the statistically significant coefficients.

11 The effects of Cyprus, Spain, Greece and Ireland are analysed separately. 
crease in funds sent to Portugal. In the case of Spain, several banks operating in Portugal with headquarters in Spain may have received Spanish financing during the crisis.

\section{CONCLUSION}

The objective of this paper was to determine how economic activity, distance, frontiers and EZ membership explain financial transactions received by Portugal via the TARGET2 System. Operations changed markedly over the period from 2006 to 2012: the concentration of operations in the three main countries (Spain, Germany and Belgium) increased considerably.

We concluded that the variables capturing the economic activities of both the country receiving funds and its partners, namely GDP, stock market capitalisation, banks' assets, or a combination of the three and also EZ membership contribute positively to incoming capital flows. But, the economic size of the partner country becomes non-significant in explaining the cross-border transfers after controlling for the country fixed effects. Distance proved unimportant to financial flows, as one would expect in an integrated market like the EU. This shows a good level of financial integration between Portugal and other EU countries with a reduced level of information asymmetry. More generally, the gravity model is not a good way of describing international interbank flows.

Our results also contribute to the debate on Portugal's possible exit from the EZ. Our estimations indicate that the country obtains financing more easily from EZ member countries than from other European countries. This suggests that if the country exited the EZ, it would face great financing difficulties.

The subprime and European sovereign debt crises affected the capital received by Portugal: we found that there was a decrease in funds received from 2007 until 2012 that is not explained by the fall in economic and financial activities. The Portuguese 10-year treasury bonds yield is very significant in explaining the incoming flow of funds. However, contrary to the expectation, the inflow of funds from some core and crisis countries has increased in the periods of economic stress. Although we advance some explanations for this, further research is needed.

Our work demonstrates that the reduction in capital flow to a crisis country is due to both a decline in economic activity and the crisis climate. This suggests that an important channel of debt crises contagion is the restriction of international funding, a phenomenon usually called Sudden Stop (Lane 2012).

This study proved that the transnational operations of TARGET2 system were affected by crises; hence, it is necessary to determine how contagion can be pre- 
vented to assure the correct functioning of these systems and to avoid the breakdown of the financial system. In the times of crisis, the ECB should facilitate the financing of banks to mitigate the funding difficulties of the affected countries. Naturally, a clear distinction should be made between a sudden stop in the inflow of funds and its normal fluctuation across the business cycle. Also, countries and financial institutions must be able to demonstrate their credibility and transparency through sound public accounts (for countries) and good levels of solvency and profitability (for financial institutions), so that markets continue to trust them.

\section{REFERENCES}

Admati, A. R. - Pfleiderer, P. (1988): A Theory of Intraday Patterns: Volume and Price Variability. The Review of Financial Studies, 1(1): 3-40.

Anderson, J. E. (1979): A Theoretical Foundation for the Gravity Equation. The American Economic Review, 69(1): 106-116.

Anderson, J. E. (2011): The Gravity Model. Annual Review of Economics, 3: 133-160.

Aviat, A. - Coeurdacier, N. (2007): The Geography of Trade in Goods and Asset Holdings. Journal of International Economics, 71(1): 22-51.

Bandt, O. - Hartmann, P. (2000): Systemic Risk: A Survey. Working PaperSeries, No. 35, Frankfurt am Main: European Central Bank.

Bank of Portugal (2010): Relatório dos Sistemas de Pagamentos 2009. Lisboa: Banco de Portugal.

Bech, M. - Preisig, C. - Soramäki, K. (2008): Global Trends in Large-Value Payments. FRBNY Economic Policy Review, September: 59-81.

Ciampolini, M. - Rohde, B. (2000): Money Market Integration: A Market Perspective. Presentation on ECB Conference on "The Operational Framework of the Eurosystem and Financial Markets”, Frankfurt am Main, May 5-6.

Daianu, D. (2012): Euro Zone Crisis and EU Governance: Tackling a Flawed Design and Inadequate Policy Arrangements. Acta Oeconomica, 62(3): 295-319.

Deardorff, A. V. (1998): Determinants of Bilateral Trade: Does Gravity Work in a Neoclassical World? In: Frankel, J. A. (ed.): Regionalization of the World Economy. University of Chicago Press, pp. 7-32.

European Central Bank (2010): TARGET Annual Report 2009. Frankfurt am Main.

Flavin, T. J. - Hurley, M. J. - Rousseau, F. (2002): Explaining Stock Market Correlation: A Gravity Model Approach. Manchester School Supplement, 70(S1): 87-106.

Frankel, J. A. (1997): Regional Trading Blocs in the World Economic System. Washington, D. C.: Peterson Institute for International Economics.

Grinblatt, M. - Keloharju, M. (2001): How Distance, Language, and Culture Influence Stockholdings and Trades. The Journal of Finance, LVI (3): 1053-1073.

Kokkola, T. (2010): The Payment System - Payments, Securities and Derivatives, and the Role of the Eurosystem. Frankfurt am Main: European Central Bank.

Lane, P. (2012): The European Sovereign Debt Crisis. The Journal of Economic Perspectives, 26(3): 49-68. 
Linnemann, H. (1966): An Econometric Study of International Trade Flows. Amsterdam: NorthHolland Publishing Company.

Loungani, P. - Mody, A. - Assaf, R. (2002): The Global Disconnect: The Role of Transactional Distance and Scale Economies in Gravity Equations. Scottish Journal of Political Economy, 49(5): 526-543.

Mamede, R. P. - Lagoa, S. - Leão, E. - Barradas, R. (2016): The Long Boom and the Early Bust: The Portuguese Economy in the Era of Financialisation. In: Hein, E. - Detzer, D. - Dodig, N. (eds): Financialisation and the Financial and Economic Crises. Country Studies. Cheltenham, UK: Edward Elgar, pp. 255-274.

Martin, P. - Rey, H. (2004): Financial Super-Markets: Size Matters for Asset Trade. Journal of International Economics, 64(2): 335-361.

Mayer, T. - Zignago, S. (2011): Notes on CEPII's Distances Measures: The GeoDist Database. CEPII Research Center Working Papers, No.25, December.

Mota, P. R. - Costa Fernandes, A. L. - Nicolescu, A. N. (2015): The Recent Sovereign Debt Crisis in the Euro Zone: A Matter of Fundamentals. Acta Oeconomica, 65(1): 1-25.

Papaioannou, E. (2009): What Drives International Bank Flows? Politics, Institutions \& Other Determinants. Journal of Development Economics, 88(2): 269-281.

Portes, R. - Rey, H. (2005): The Determinants of Cross-Border Equity Flows. Journal of International Economic, 65(2): 269-296.

Portes, R. - Rey, H. - Oh, Y. (2001): Information and Capital Flows: The Determinants of Transactions in Financial Assets. European Economic Review, 45(4-6): 783-796.

Pröpper, M. - Lelyveld, I. van - Heijmans, R. (2008): Towards a Network Description of Interbank Payment Flows. DNB Working Paper, No. 177, Netherlands Central Bank, Research Department, May.

Rosati, S. - Secola, S. (2006): Explaining Cross Border Large Value Payment Flows Evidence from TARGET and EURO I Data. Journal of Banking and Finance, 30(6): 1753-1782. 


\section{APPENDIX}

Table A1. Weight of each country in the operations received

\begin{tabular}{l|c|c|c|l|c|c|c}
\hline Country & 1999 & 2006 & 2012 & Country & 1999 & 2006 & 2012 \\
\hline Germany & 28.10 & 16.39 & 26.08 & Greece & 0.067 & 0.86 & 3.24 \\
\hline Austria & 2.35 & 1.93 & 0.15 & England & 11.13 & 10.74 & - \\
\hline Belgium & 17.43 & 11.35 & 14.33 & Ireland & 1.08 & 5.09 & 0.02 \\
\hline Bulgaria & - & - & 0.0005 & Italy & 6.42 & 10.78 & 0.50 \\
\hline Cyprus & - & - & 0.01 & Latvia & - & - & 0.003 \\
\hline Denmark & 1.58 & 2.67 & 0.24 & Lithuania & - & - & 0.001 \\
\hline Slovakia & - & - & 0.001 & Luxembourg & 2.36 & 1.91 & 5.14 \\
\hline Slovenia & - & - & 0.001 & Malta & - & - & 0.04 \\
\hline Spain & 12.45 & 20.25 & 40.87 & Netherlands & 4.31 & 3.42 & 2.60 \\
\hline Estonia & - & - & 0.0002 & Poland & - & - & 0.14 \\
\hline Finland & 0.34 & 1.69 & 0.27 & Romania & - & - & 0.02 \\
\hline France & 11.95 & 12.58 & 6.33 & Sweden & 0.35 & 0.32 & - \\
\hline & & & & Total & 100 & 100 & 100 \\
\hline
\end{tabular}

Source: Elaborated by the authors with data provided by Bank of Portugal.

Table A2. Descriptive statistics

\begin{tabular}{l|l|l|r|r|r|r}
\hline Variable & $\begin{array}{l}\text { Unit of } \\
\text { measurement }\end{array}$ & Obs. & Mean & Std. Dev. & Min. & \multicolumn{1}{c}{ Max. } \\
\hline$R_{, . t}$ & Million euro & 220 & 85495.4 & 108771.7 & 2 & 588351 \\
\hline$S M C P_{t}$ & Million euro & 220 & 58140.08 & 12714.91 & 40872 & 89798 \\
\hline$S M C_{j, t}$ & Million euro & 220 & 436046.3 & 594797.6 & 831 & 2919317 \\
\hline$B S P_{t}$ & Million euro & 220 & 423928.9 & 111636.8 & 249367 & 573310 \\
\hline$B S_{j, t}$ & Million euro & 220 & 1984551 & 2416379 & 24405 & 9969911 \\
\hline$G D P P_{t}$ & Million euro & 220 & 153756.8 & 4611.107 & 142461 & 160205 \\
\hline$G D P_{j, t}$ & Million euro & 220 & 615845.9 & 708561.4 & 5315 & 2467972 \\
\hline$T B P_{t}$ & $\%$ & 220 & 4.650246 & 1.975631 & 1.401667 & 22.56417 \\
\hline$T B_{t, j}$ & $\%$ & 220 & 5.659409 & 2.339984 & 3.44 & 10.54905 \\
\hline$D_{j}$ & Kilometre & 220 & 2136.623 & 734.676 & 501 & 3766 \\
\hline$B_{j}$ & - & 220 & .0636364 & .2446607 & 0 & 1 \\
\hline EA $_{j}$ & - & 220 & .7772727 & .4170256 & 0 & 1 \\
\hline$D C r i s e s_{t}$ & - & 220 & .4909091 & .5010574 & 0 & 1 \\
\hline
\end{tabular}

